JOANNA MichALAK-DAWIDZIUK

ORCID 0000-0003-1574-542X

Wyższa Szkoła Menedżerska

w Warszawie

\title{
SELECTED ASPECTS OF THE TEACHING PROFESSION IN POLAND
}

\begin{abstract}
Aвsтract. Michalak-Dawidziuk Joanna, Selected Aspects of the Teaching Profession in Poland [Zawód nauczyciela w Polsce - wybrane aspekty]. Studia Edukacyjne nr 60, 2021, Poznań 2021, pp. 135-160. Adam Mickiewicz University Press. ISSN 1233-6688. DOI: 10.14746/se.2021.60.8

This article was written on the basis of the text created by the author as part of the Polish component of the Reducing Early School Leaving in the EU project carried out within the $7^{\text {th }}$ Framework Program of the European Union for the years 2013-2018. The text was prepared when the author followed a research apprenticeship program at the Faculty of Education of the University of Warsaw. The article describes the teacher's profession over the past fifteen years, placing special emphasis on teachers' education, teachers' careers, rules for and structure of employment.
\end{abstract}

Key words: teacher education, teaching profession, employment rules and structure, teaching career

\section{Introduction}

Social, political and economic transformation observed in Poland since 1989 has started a process of profound changes in the education system, which affected the teaching profession, too. Challenges resulting from the implementation of successive education reforms, as well as extensive changes that occur globally, make teaching an extremely challenging profession, which requires not only knowledge, but also skills and social competencies that enable undertaking and carrying out new tasks.

Lexicon of Labour Pedagogy provides the following definition of a profession:

performing sets of socially useful activities, distinguished as a result of the division of labour, requiring from an employee relevant knowledge and skills, as well as psychological and physical features, which condition the performance of professional tasks 
that are systematically repeated and form a source of income for the employee and their family. A profession accords prestige and social standing to an employee. Social consequences of practising a profession include the possibility for its representatives to associate, cultivate the traditions of a profession, present specific attitudes and social assessments made from the perspective of a given profession. ${ }^{1}$

Therefore, practising any profession requires openness to continuing development of skills and social competencies. This issue becomes particularly important in the context of the teaching profession, which involves constant contact with students, their parents, other teachers, as well as with the school environment, including, among others, the school governing authority (a competent local government unit; commune, county, province), the supervisory authority (relevant schools superintendent, minister competent for education), non-governmental organisations and other public and non-public institutions. Such a wide spectrum of subjects and people with whom teachers need to cooperate requires various social competencies, which guarantee properly established relations with stakeholders. A growing number of entities with whom teachers need to cooperate and challenges resulting from dynamic changes in their environment make the list of required competencies constantly expand.

A changing society and new social expectations concerning their work posed a challenge for teachers. Not only were teachers required to be specialists in the fields they teach and act as excellent pedagogues who are capable to work with children with various educational needs, but also the importance of the competencies related to the obligation to work more closely with other teachers, parents and the local community was stressed. ${ }^{2}$

\section{Thus,}

the higher the level of social competencies, the better communication with stakeholders, which is combined with better understanding them, making more accurate decisions, more flexible adapting to change, and better functioning in work environment. ${ }^{3}$

Emotional competencies have become particularly important in the process of change, and shaping them

(...) can result in resilience and the ability to cope in challenging situations and can contribute to helping others, gaining control over actions taken and perseverance in

${ }^{1}$ T.W. Nowacki, Leksykon pedagogiki pracy, Radom, p. 287.

2 A. Wiłkomirska, A. Zielińska, Ocena systemu promocji zawodowego nauczycieli w Polsce, Warszawa 2013, p. 9.

${ }^{3}$ J. Michalak-Dawidziuk, Kompetencje społeczne a utopia, [in:] Utopia and Education, Ed. R. Włodarczyk, Vol. II, Wrocław 2017, p. 190. 
the performance of tasks, as well as overcoming disappointments and facing various challenges. ${ }^{4}$

Within the framework of education system reforms, major changes have been introduced in all areas of the system of education, including: the structure of education system, timetables and curricula, the system of assessment, pedagogical supervision, the system of teacher continuing professional development, schools and educational institutions funding, as well as the system of teachers' professional advancement, "(...) which could encourage them to raise their qualifications, improve their professional skills, and to act and cooperate with the aim of enhancing the quality of school work". 5

The authors of subsequent changes introduced in the education system assume that teachers are the foundation of a modern school. By acquiring new competencies as part of the reformed system of professional advancement, they should become guarantors of improved quality of children's and youth's education.

Teachers are expected to be professional, thanks to which students can become prepared for adult life in a dynamically changing environment.

The dynamics of change puts teachers in a very difficult situation, as its pace is often faster than that of introducing formal organisational solutions. In many cases, teachers can only relay on their own experience and intuition. ${ }^{6}$

Teachers are perceived as professional having particular importance for introduced changes. Hence, initial teacher training and professional advancement system, perceived as paths for continuing professional development leading to attaining mastery in the profession, coupled with employee pragmatics are factors determining the decision to pursue the teaching profession and the quality of work. Thus, conditions in which teachers operates can determine both interest in the profession and, at a later stage, staying in the profession.

\section{Initial teacher education - overview Review of literature on initial teacher education}

Many researchers analysed initial teacher education, to mention $\mathrm{Cz}$. Banach (1998), R. Branderburg, A. McDonough, J. Burke (2016), A.W. Combs,

${ }^{4}$ J. Madalińska-Michalak, R. Góralska, Kompetencje społeczne nauczyciela, Warszawa 2012, p. 110.

${ }^{5}$ A. Wiłkomirska, A. Zielińska, Ocena systemu promocji zawodowego, p. 9.

${ }^{6}$ J. Michalak-Dawidziuk, System awansu zawodowego nauczycieli a transgresyjna postawa nauczycieli, [in:] Transgresja jako motyw refleksji nad wychowaniem, Eds. A. Ciążela, S. Jaronowska, Warszawa 2017, p. 105. 
R.A. Blume, A.J. Newman, H. L. Wass (1978), R. Forgasz (2016), B. Gołębniak (1998), J.M. Gore (2016), I. Jones (2017), D. O'Keeffe (2003), H. Kwiatkowska $(1988,1997)$, T. Lewowicki $(1985,2007)$, J. Loughran (2006), A. Moore (2012), J. Niemiec (1995), W. Okoń (1988, 1991), R. Pachociński (1994), A. Pearson (1994), J. Szempruch (2000, 2000A, 2013), M. Waring, C. Evans (2014), A. Wiłkomirska (2005), A. Wiłkomirska, and A. Zielińska (2013). The multitude of approaches and theories have become a part of the process of searching for increasingly effective methods of initial teacher training, and also bear testimony to continuing improvement of its quality. The selection of concepts discussed in this text is a result of limitations imposed by formal requirements relating to the volume of the article.

When defining initial teacher training, H. Kwiatkowska lists three orientations: technological, humanistic and functional one. Technological orientation derives from behavioural concept of a reactive human being, whose behaviour results from reactions to random external stimuli. Supporters of behavioural psychology claim that "everything that is either good or bad in humans is the expression of environment's manipulation". ${ }^{7}$ This means that behaviourists did not subscribe to the model of an independent human, whose actions result from internal motives. This meant that

in the process of education, it is sufficient to create an objective environment, which by means of a system of appropriate rewards and penalties would reinforce the desirable behaviour and inhibit the types of behaviour that should be eliminated". 8

In technological orientation, knowledge was a determinant of teachers' qualifications. The characteristic features of initial teacher education included:

- marginalising the importance of theoretical knowledge, which is so much needed in complex problem solving and at the same time emphasising the importance of "equipping teachers with a catalogue of skills useful in action",

- omitting axiological issues and removing such notions as values, freedom and dignity and focusing on drills rather than empirical cognition,

- a high degree of control over the process of initial teacher education, which is manifested by:

first of all, the aim of the process of initial teacher education is to drill into specific skills needed to perform teaching tasks and organise cognitive processes.

Secondly, the process of initial teacher education is much more strongly dominated by praxeological (organizational, economic, ergonomic) norms than by moral social, ethical and aesthetic standards.

${ }^{7}$ H. Kwiatkowska, Nowa orientacja w ksztatceniu nauczycieli. Założenia i metody edukacji nauczycielskiej, Warszawa 1988, p. 25.

${ }^{8}$ Ibidem, p. 24-25.

9 Ibidem, p. 24. 
Thirdly, the high degree of control over the process of initial teacher education is confirmed by didactic techniques used, which mainly focus on shaping pre-programmed responses of the learners. ${ }^{10}$

According to $\mathrm{H}$. Kwiatkowska, serious imperfections of technological orientation result from the lack of humanistic dimension of this orientation.

The humanistic orientation has seen a change in "(...) the way of thinking: from behaviouristic to personalistic"; $; 1$ in the process of good teaching the focus has been shifted from mechanistic to humanistic approach. ${ }^{12}$ This forms a reference to a view presented by A.W. Combs who believed that ... "A good teacher is first and foremost a person, and this fact is the most important and determining thing about him". ${ }^{13}$ With regard to teacher education, A.W. Combs referred to three principles of humanistic psychology: a) a human being is a direct result of their field of perception, b) out of all perceptions, self-perception is the most important one, c) in order to function more efficiently, each person needs self-esteem. ${ }^{14}$ The humanistic orientation stems from the view that "a good teacher is above all a unique personality". ${ }^{15}$ The most important goal of teacher education is to support future teachers in discovering their own individuality and uniqueness. According to H. Kwiatkowska, initial teacher education from humanistic perspective is "(...) looking for a path leading to yourself and finding yourself" ${ }^{16}$ When discussing the concept proposed by A.W. Combs, H. Kwiatkowska pointed out that:

By and large, in his concept, Combs does not speak about the process of education with respect to acquiring knowledge and skills, but about the process of becoming a teacher. ${ }^{17}$

The humanistic orientation, which is completely different from technological one, is in opposition to technical understanding of the teaching profession. It treats teachers as subjects who refer to their intellect and feelings when solving problems in their pedagogical work. Therefore, "a teacher education programme should focus on personalities rather than on competencies" ${ }^{18}$ This orientation also negates "the value of (...) teacher training

${ }^{10}$ Ibidem, p. 28-29.

11 Ibidem, p. 29.

${ }^{12}$ H. Kwiatkowska, Edukacja nauczycieli. Konteksty - kategorie - praktyki, Warszawa 1997, p. 196.

${ }^{13}$ A.W. Combs et al., The Professional Education of Teachers, Boston Allyn and Bacon, Inc., 1978, p. 6.

${ }^{14}$ H. Kwiatkowska, Pedeutologia, Warszawa 2008, p. 85-86.

${ }^{15}$ H. Kwiatkowska, Nowa orientacja w ksztatceniu nauczycieli, p. 30.

${ }^{16}$ Ibidem, p. 28-29.

${ }^{17}$ H. Kwiatkowska, Edukacja nauczycieli, p. 203.

18 A.W. Combs et al., The Professional Education of Teachers, p. 9. 
programmes that focus on course contents", ${ }^{19}$ because "course contents are not an intrinsic value, and are valuable as long as they perform certain functions in the structure of teachers' professional activities".$^{20}$ In humanistic orientation, teaching practice forms an integral part of teacher education programmes, as it allows students gain hands-on experience in teaching. However, teaching practice should be progressively implemented to grade the level of difficulty, i.e. initially a trainee teacher should work with one student and then move on to working with groups thus assuming more and more responsible roles. The aim of this approach is to limit or eliminate negative experiences in the education process. In humanistic orientation, attention is drawn to the fact that "teaching practice should be organised in such a way as to limit students' negative experiences related to their own pedagogical activity"21. This is important, because it contributes to a "positive self-image". ${ }^{22}$

In functional orientation, teacher education is characterised by a task-oriented training, in which knowledge of reality is acquired through various actions taken in real-life or simulated situations. The acquisition of the ability to apply theoretical knowledge in practice is particularly important in the process of teacher education. At the same time, an important role is assigned to knowledge reserve that can be used in action, which $\mathrm{H}$. Kwiatkowska describes as "surplus qualifications" 23 . According to the author, "The greater reserve of seemingly superfluous knowledge, the greater use is made of knowledge that is operationally indispensable or knowledge that forms necessary indicative basis for action" 24 . Taking into account the fact that the awareness of the roots of knowledge and methods of discovering it forms the basis for knowledge functionality, instilling research attitudes in teachers, which will allow them to take adequate and effective actions, takes an important place in functional orientation. At the same time, in order to act as subjects of action, teachers are expected to strive to gain self-knowledge and self-awareness. It is worth mentioning here a view of Z. Pietrasiński who believes that "(...) in initial teacher education, the most important learning outcome is the ability to adapt behaviour to changing situation, and not stereotypical components of each new skill"25. Flexibility, combined with adequacy and efficiency, is strongly emphasised in functional orientation, hence the creation of situations

\footnotetext{
${ }^{19}$ H. Kwiatkowska, Nowa orientacja w ksztatceniu nauczycieli, p. 42.

${ }^{20}$ Ibidem, p. 42-43.

${ }^{21}$ Ibidem, p. 46.

${ }^{22}$ Ibidem.

${ }^{23}$ Ibidem, p. 64.

${ }^{24}$ Ibidem.

${ }^{25}$ Z. Pietrasiński, Wstęp do czynnościowej teorii ksztatcenia umystu, [in:] Studia nad teoria czynności ludzkich, Eds I. Kurcz, J. Reykowski, Warszawa 1975, p. 196.
} 
that allow to acquire these skills in education process. However, they do not merely represent technical skills, but should have an ethical and moral dimension, given that

the purpose of teachers' work is (...) not only to teach how to get to know the world and how to effectively operate in it, but also to teach how to live in this world, and especially how to live in a dignified way. ${ }^{26}$

Apart from the three orientations of initial teacher education described above, there is also an axiological orientation, which focuses on placing an individual in a system of historical and anthropological values, their developmental potential, values that support a person in shaping their personality, "and in education process - justify the selection of contents, methods and educational goals" ${ }^{27}$

Competent teaching depends on three factors: subject knowledge, structured knowledge of teaching and reflective practical experience. ${ }^{28}$

An interesting view was presented by A. Pearson who emphasised the importance of comprehensive character of teaching in the process of teacher education, where the concept of comprehensive activity is understood as

such an activity, in which original intentions can be altered by a given situation. (...)

Such an activity can also be described as interactive one (...). ${ }^{29}$

It means that teachers should adapt their actions to a situation they are in. Thus, comprehensive character of teaching is understood as "an interaction between the intentions of a teacher and the events and circumstances of teaching". ${ }^{30}$

According to H. Kwiatkowska, when developing teacher education programmes, you should take into consideration the fact that

(...) a teacher's work is characterized by imprecision, lack of standardisation, volatility of situation, and lability of working conditions. It cannot be easily formalised, like it is the case with simple types of work. ${ }^{31}$

${ }^{26}$ H. Kwiatkowska, Nowa orientacja w ksztatceniu nauczycieli, p. 67.

${ }^{27}$ A. Rumiński, Aksjologia pedagogiczna w kształceniu nauczycieli, [in:] Akademicka edukacja nauczycieli. Z problemów metodologii, teorii i praktyki, Ed. K. Duraj-Nowakowska, Kraków 1993, p. 133.

${ }^{28}$ The Holmes Group Tomorrow's Teachers, East Lansing, The Holmes Group 1986, p. 62.

29 A. Pearson, Nauczyciel. Teoria i praktyka w ksztatceniu nauczycieli, Warszawa 1994, p. 145.

${ }^{30}$ Ibidem, p. 147.

${ }^{31}$ H. Kwiatkowska, Pedeutologia, p. 205-206. 
According to the author, teacher education presently requires:

1) a contemporary context for the operation of education; 2) changes in the area of professional responsibilities of teachers; 3 ) changes in the concept of teacher education conditioned by social change. ${ }^{32}$

The process of teacher training in individual countries is subject to analyses, which point to weaknesses in the way students are trained for the teaching profession.

In 2014, A report by Australian Teacher Education Ministerial Advisory Group (TEMAG, 2014) showed that during the professional experience (PE) component of initial teacher education "the quality of professional experience is limited by a lack of integration of theory and practice, and by a lack of integration of the work of providers and schools. ${ }^{33}$

When listing the main challenges of teacher education discussed in literature on the topic, R. Forgasz mentioned: the lack of adequate practical training preparing for teaching practice (Shulman, 1986), which resulted in unsatisfactory teacher learning outcomes (Zeichner \& Tabachnick, 1981) and relatively low level of student satisfaction (Gore, Griffiths, et.al, 2004), as well as the lack of confidence in their skills and lack of confidence in how well prepared they are (McKenzie, Weldon, Rowley, Murphy and McMillan, 2014). ${ }^{34}$ D. O'Keeffe pointed out the shortcomings of the teacher education system in Great Britain and stated that

(...) the problem of British teacher education is the lack of knowledge on what kinds of teachers are needed. Over the past decade, British governments have recognised this to some extent, because when teaching BEd courses they have focused on an important element of specialist knowledge - English, mathematics, history or IT. ${ }^{35}$

${ }^{32}$ H. Kwiatkowska, Kształcenie nauczycieli, [in:] Encyklopedia pedagogiczna XXI wieku, Vol. 2, Ed. T. Pilch, Warszawa 2003, p. 879.

${ }_{33}$ R. Forgasz, Rethinking the Observation Placement: A Community/Cohort Approach to Early Professional Experiences, [in:] Teacher Education. Innovation, Intervention and Impact, Eds R. Brandenburg, A. McDonough, J. Burke, Singapore 2016, p. 99. In the above quote an excerpt has been used from the report of Teacher Education Ministerial Advisory Group (TEMAG) (2014) Action now: Classroom ready teachers, Canberra, Australia: Department of Education and Training. p. 25.

${ }^{34}$ J.M. Gore, Reform and the Reconceptualisation of teacher education in Australia, [in:] Ibidem,

35 D. O'Keeffe, Teacher education in Britain, Edukacja, 2003, 3(83), p. 102. The term BEd used in the text refers to the level of education that existed in the UK in the 1980s. and offered qualifications for teaching in primary and secondary schools. Nowadays, BED's role has been marginalised and it does not even provide qualifications for working in primary schools. BEd is to be replaced by BAs and BSsc. 
The challenges mentioned by these authors also apply to Polish system of teacher education. This is why for several years reforms of the system have been introduced.

\section{Polish legislation on teacher education binding from 2005 to 2019}

Teacher education in Poland is provided at the level of higher education, which is subject to major changes resulting from the implementation of the Bologna Process aimed at the creation of the European Higher Education Area. The implemented changes also concern initial teacher education. When analysing legal regulations adopted over the past fifteen years, the following instruments should be mentioned:

- Act of 27 July 2005 Law on Higher Education (O.J. of 2005, No. 164, item 1365 as amended);

- Act of 20 July 2018 Law on Higher Education and Science (O.J. of 2020, item 85);

- Order of the Minister of Science and Higher Education of 12 July 2007 on education standards for particular degree programmes and levels of education, as well as the mode for their establishment and conditions to be met by higher education institutions in order to provide interdisciplinary studies and macro-degree programmes (O.J. of 2007, item 164, 1166 as amended);

- Order of the Minister of Science and Higher Education of 17 January 2012 on the standard of initial teacher education (O.J. of 2012, item 131);

- Order of the Minister of Science and Higher Education of 25 July 2019 on standards of initial teacher education (O.J. of 2019, item 1450).

In accordance with legal regulations in force since 2005, initial teacher education has been provided at the level of first-cycle studies (bachelor's degree studies) and second-cycle studies (supplementary master's degree studies). At the same time, law allowed for a possibility to obtain teaching qualifications as a result of completing first- or second-cycle studies as part of a degree programme different than pedagogy and post-graduate teacher training programmes. The notion of preparation in pedagogy (Polish: przygotowanie pedagogiczne) was defined many years ago in an order of the minister competent for education and has remained in force until now despite numerous amendments or changes to the order. Therefore, in this text reference is made to the binding order of the Minister of National Education of 1 August 2017, which defines the concept of preparation in pedagogy as:

the acquisition of knowledge and skills in the field of psychology, pedagogy and detailed didactics, taught for not less than 270 contact hours in connection with a de- 
gree programme (speciality) and positively assessed teaching practice amounting to at least 150 hours; in the case of vocational education and training teachers, the required number hours of a preparation in pedagogy programme should be not less than 150; a higher education graduation diploma or other document issued by a higher education institution or a diploma attesting the completion of a programme offered by a teacher training institution or a certificate of completion of a qualification course are documents attesting the completion of preparation in pedagogy. ${ }^{36}$

Study plans and programmes developed on the basis of the executive act to the Act of 27 July 2005 Law on Higher Education (O.J. of 2005, No. 164, item 1365 as amended) i.e. the Order of the Minister of Science and Higher Education of 12 July 2007 on education standards for particular degree programmes and levels of education, as well as the mode for their establishment and conditions to be met by higher education institutions in order to provide interdisciplinary studies and macro-degree programmes (O.J. of 2007, item 164, 1166 as amended) provided that education offered as part of first-cycle degree programmes in pedagogy lasted six semesters (at least 1800 hours, 180 ECTS credits) and as part of second-cycle degree programmes lasted at least four semesters (at least 800 hours, 120 ECTS credits).

The above order stipulated that general courses taught as part of first-cycle programmes amounted to 330 hours and speciality courses amounted to 210 hours. The group of general courses included: philosophy, psychology, sociology and pedagogical concepts and systems, while the group of speciality-related courses included: history of pedagogical thought, theoretical basis of education, and social pedagogy. Degree programmes in pedagogy also included an eight-week teaching practice. Among other requirements, teaching such courses as: physical education (60 hours), languages (120 hours), information technology (30 hours), courses containing contents that broaden general knowledge, including biomedical basis of development and education (60 hours) was decreed. In addition, teaching about intellectual property protection, health and safety at work and ergonomics was required. The remaining hours were to be devoted to the teaching of speciality courses, including the teaching speciality.

As in the case of first-cycle studies, the order provided for two groups of courses taught as part of second-cycle programmes: general courses amounting to 180 hours (24 ECTS credits) and speciality courses amounting to 120 hours (16 ECTS credits). The group of general courses included these in: anthropology of culture, logic, methodology of social research, contemporary concepts in philosophy and ethics, contemporary problems in sociology, contemporary problems in psychology. The group of speciality courses in-

${ }^{36}$ Article 2 of the Order of the Minister of National Education of 1 August 2017 on detailed qualifications to be held by teachers (O.J., item 1575). 
cluded these in: andragogy, general pedagogy, comparative pedagogy and pedeutology. Other requirements included the need to teach courses in health education and health promotion. The remaining hours were to be devoted to the teaching of speciality courses, including the teaching speciality.

Another legal regulation on teacher education was adopted after the fiveyear period of the above mentioned order staying in force. It defined in more detail the development of initial teacher education programmes. The Order of the Minister of Science and Higher Education of 17 January 2012 on the standard of initial teacher education (O.J. 2012, item 131) provided for five modules: module 1: content-related preparation for teaching the first subject (for specialist teachers), module 2: preparation in the scope of psychology and pedagogy, module 3: preparation in the scope of didactics, module 4: content-related preparation for teaching another subject (semi-specialist teachers), and module 5: preparation in the scope of special needs pedagogy. As part of individual modules, the following components and numbers of hours were specified:

- module 1: content-related preparation - in accordance with the description of learning outcomes for a given degree programme (the number of hours ensured content-related preparation for teaching the subject (specialist teachers));

- module 2: general preparation in the scope of psychology and pedagogy (90 hours), preparation in the scope of psychology and pedagogy for teaching at a given education stage or stages (60 hours), teaching practice ( 30 hours);

- module 3: introduction to didactics (30 hours), subject teaching (type of class) at a given education stage or stages ( 90 hours), teaching practice (120 hours);

- module 4: content-related preparation (the number of hours ensured content-related preparation for teaching the subject (semi-specialist teachers), subject teaching (type of class) at a given education stage or stages (60 hours), teaching practice (60 hours);

- module 5: preparation in the scope of special needs pedagogy and psychology (140 hours), teaching students with special educational needs (90 hours), teaching practice (120 hours).

Higher education institutions offering first-cycle (bachelor's degree) and second-cycle (supplementary master's degree) programmes are authorised to teach initial teacher education programmes. The level of required studies depends on education stage future teachers will work at. In accordance with the order on standard of initial teacher education, ${ }^{37}$ holders of the following qualifications are authorised to teach:

${ }^{37}$ Order of the Minister of Science and Higher Education of 17 January 2012 on the standard of initial teacher education (O.J. of 2012, item 131). 
a) in kindergartens and primary schools: graduates of first-cycle studies who have been awarded bachelor's degree (Polish: licencjat);

b) in lower- and upper-secondary schools: graduates of second-cycle programmes who have been awarded a master's degree (Polish: magister).

Initial teacher education in the scope of teaching the first subject (specialist teachers) consists in three obligatory modules, covering content-related preparation in the scope of the subject to be taught, preparation in the scope of psychology and pedagogy and preparation in the scope of didactics.

The six-year period of the order staying in force was ended by adoption of the Law of 20 July 2018. Law on Higher Education and Science (O.J. of 2020, item 85), which stipulates more precise regulations on initial teacher education. In accordance with new regulations, only higher education institutions holding scientific category $\mathrm{B}$ in the discipline to which a given degree programme is assigned can provide initial teacher education. During a transition period, also higher education institutions, which have signed an agreement with a higher education institution holding the B category can offer such education. Pursuant to the Order of the Minister of Science and Higher Education of 25 July 2019 on standard of initial teacher education (O.J. of 2019, item 1450), initial teacher education programmes should include the following groups of courses, as part of which students should achieve detailed learning outcomes:

1) content-related preparation in the scope of teaching the first subject or teaching the first type of class (specialist teachers);

2) content-related preparation in the scope of teaching another subject or teaching another type of class (semi-specialist teachers);

3) preparation in the scope of psychology and pedagogy;

4) introduction to teaching and voice projection, and

5) preparation in the scope of teaching the first subject or the first type of class (specialist teachers).

In group 1) Content-related preparation in the scope of teaching the first subject or teaching the first type of class, and 2) content-related preparation in the scope of teaching another subject or teaching another type of class the number of hours of courses taught indicated in the study programme ensures content-related preparation for teaching a given subject or a type of class. In group 3) Preparation in the scope of psychology and pedagogy, courses in psychology (90 hours), pedagogy (90 hours), and teaching practice (30 hours) are included with a total number of 10 ECTS credits. In group 4) Introduction to teaching and voice projection, courses in introduction to teaching and voice projection are included with a total number of 60 hours and 3 ECTS credits. In group 5) Preparation in the scope of teaching the first subject or the first type of class; 
- in the case of the subject or classes taught in primary and secondary schools, theoretical vocational subjects and practical vocational training: a course in teaching the subject or type of class (150 hours), teaching practice (120 hours) with a total number of 15 ECTS credits.

- in the case of a subject or classes taught in primary or secondary schools:

$\circ$ a course in teaching the subject or type of class ( 90 hours), teaching practice (60 hours)

with a total number of 7 ECTS credits.

In the group of courses Preparation in the scope of teaching another subject or type of class;

- in the case of the subject or classes taught in primary and secondary schools, theoretical vocational subjects and practical vocational training: a course in teaching the subject or type of class (90 hours), teaching practice (90 hours) with a total number of 7 ECTS credits.

- in the case of a subject or classes taught in primary or secondary schools: a course in teaching the subject or type of class (60 hours), teaching practice (60 hours) with a total number of 6 ECTS credits.

In the group of courses Pedagogical preparation for practising the profession of a school psychologist: pedagogy (60 hours), methodology of a school teacher's work in kindergartens, schools and other institutions of the system of education (120 hours), teaching practice (120 hours) with a total number of 14 ECTS credits.

The provision of the Law on Higher Education and Science concerning the number of hours of teaching practice is noteworthy.

As part of introduced changes, the possibility of providing education as part of a practical and general academic profile was offered. In the case of practical profile, more than $50 \%$ of ECTS credits are allocated to courses teaching practical skills, while in the case of general academic profile more than $50 \%$ of ECTS credits are allocated to courses related to the HEI's academic activities. ${ }^{38}$ In addition, in the case of practical profile study programmes include teaching practice lasting 6 months (first-cycle studies) and 3 months (second-cycle studies). ${ }^{39}$

The 2019 order on the standard of initial teacher education differentiates between the lengths of initial teacher education programmes. In the case of specialist teachers, teachers of theoretical vocational subjects, practical vocational training teachers, teachers teaching a particular type of class, education can be provided in the form of "first- and second-cycle degree programmes or

\footnotetext{
${ }^{38}$ Art. 64(2) of the Act on Higher Education and Science (O.J. of 2020, item 85).

${ }^{39}$ Art. 67(5)(1, 2) of the Act on Higher Education and Science (O.J. of 2020, item 85).
} 
a long-cycle master's degree programmes, for which study programmes define learning outcomes including knowledge and skills corresponding to all requirements of a relevant core curriculum for teaching a given subject or core curriculum for programmes offering initial teacher education or corresponding to the contents of classes to be taught". ${ }^{40}$

In the case of kindergarten and early school education teachers (grade 1-3 of primary school), initial teacher education is provided as part of long-cycle master's degree programmes (lasting 9 semesters at minimum). These programmes include courses amounting to 2,860 contact hours at minimum, teaching practice included. ${ }^{41}$

Degree programmes in pedagogy for special educational needs provided in the form of long-cycle master's degree programmes offer training for special educational needs teachers, speech therapy teachers and teachers conducting early child development support classes:

1) they include speciality in:
a) education and rehabilitation of people with hearing impairment (sur- dopedagogy);
b) education and rehabilitation of people with visual impairment (ty- phlopedagogy);
c) education and rehabilitation of people with intellectual impairment;
d) therapeutic pedagogy;
e) education and therapy for learners with autism spectrum disorder,
f) inclusive education;
2) they include speciality in:
a) social reintegration pedagogy;
b) speech therapy;
c) corrective pedagogy (pedagogical therapy);
d) early childhood development support.

Degree programmes in pedagogy for special educational needs last at least nine semesters and include at least 2,690 contact hours. In the case of degree programmes for speech therapy teachers the number of contact hours is 3,090 .

The above analysis of legal regulations that were in force from 2005 to 2019 allows to reach a conclusion that the changes in initial teacher education consistently aimed at a higher degree of specialisation and imposing more detailed requirements. The most recent changes introduced in 2018 and 2019 mainly focused on providing students with opportunities to gain practical

\footnotetext{
${ }^{40}$ Annex no. 1 to the Regulation of the Minister of Science and Higher Education of 25 July 2019 on the standard of initial teacher education (O.J. of 2019, item 1450), p. 2.

${ }^{41}$ Order of the Minister of Science and Higher Education of 25 July 2019 on the standard of initial teacher education (O.J. of 2019, item 1450).
} 
experience and become well prepared for entering the labour market. Hence the large number of hours of teaching practice in practical profile programmes.

\section{Teaching profession in Polish labour market}

Practising the teaching profession in Polish system of education is subject to fulfilling the requirements set out in national regulations, i.e. the Act of 26 January 1982. Teacher's Charter (O. J. of 2019, item 2215), the Order of the Minister of National Education of 1 August 2017 on detailed qualifications to be held by teachers (O.J. of 2019, item 1575, as amended), and in the case of schools of arts, the Order of the Minister of Culture and National Heritage of 20 May 2014 on detailed qualifications to be held by arts schools teachers, arts education institutions and in-service teacher training institutions (O. J. of 2014, item 784).

General requirements for teaching positions, as defined in the Teacher's Charter, are: completing a higher education programme and adequate preparation in pedagogy or completing a programme provided by a teacher training institution (in the case of taking up a job in a position for which these are sufficient qualifications), observance of basic moral principles and fulfilment of health conditions necessary for practising the profession. ${ }^{42}$ Detailed requirements concerning qualifications for particular types of schools are set out in an Order of the Minister of National Education.

In Polish schools, teachers are employed on the basis of employment contracts. In public schools, two types of employment relationships apply, i.e. on the basis of an employment contract or appointment. In accordance with the Teacher's Charter act, a person who does not hold a professional advancement grade on the date of establishing an employment relationship at school is awarded the grade of a trainee teacher. ${ }^{43}$ Having obtained the grade of a contract teacher, which is another step on professional advancement ladder, such a person can conclude an open-ended employment contract. Appointed and chartered teachers are employed on the basis of formal appointment.

The table below presents the number of teachers in service in 2013 and 2019 divided by province.

${ }^{42}$ Pursuant to Article 9(1) of the act of 26 January 1982 Teacher's Charter (O. J. of 2019, item 2215).

43 Art. 9a(2) of the act of 26 January 1982 Teacher's Charter (O. J. of 2019, item 2215). 
Table 1

The number of teachers employed in the school year 2013 and 2019 divided by province

\begin{tabular}{|l|c|c|}
\hline \multirow{2}{*}{\multicolumn{1}{c|}{ Province }} & \multicolumn{2}{c|}{ Number of teachers } \\
\cline { 2 - 3 } & Year 2013 & Year 2019 \\
\hline Dolnośląskie & $32,035.20$ & 34,063 \\
\hline Kujawsko-Pomorskie & $26,303.54$ & 27,119 \\
\hline Lubelskie & $28,899.67$ & 29,727 \\
\hline Lubuskie & $12,280.96$ & 12,718 \\
\hline Łódzkie & $30,017.20$ & 31,135 \\
\hline Małopolskie & $43,998.69$ & 48,618 \\
\hline Mazowieckie & $67,953.89$ & 78,125 \\
\hline Opolskie & $12,256.00$ & 12,234 \\
\hline Podkarpackie & $29,223.83$ & 30,503 \\
\hline Podlaskie & $15,144.30$ & 15,735 \\
\hline Pomorskie & $28,796.03$ & 32,025 \\
\hline Śląskie & $53,666.86$ & 57,144 \\
\hline Świętokrzyskie & $15,932.10$ & 15,968 \\
\hline Warmińsko-Mazurskie & $17,885.23$ & 18,351 \\
\hline Wielkopolskie & $44,649.44$ & 48,026 \\
\hline Zachodniopomorskie & $20,188.71$ & 20,864 \\
\hline Total & $479,231.65$ & 512,354 \\
\hline
\end{tabular}

Source: Own work based on: GUS, Oświata i wychowanie 2012/13, p. 250-251 http://stat.gov.pl and GUS, Oświata i wychowanie 2018/19, p. 200-201 http:/ / stat.gov.pl.obszary-tematyczne/edukacja

The table presented above shows that both in 2013 and 2019, chartered teachers formed the most numerous group. There were 240,579.96 and 286,790 of them, respectively. Appointed teachers formed the second most numerous group amounting to 130,325.80 and 103,98, followed by contract teachers: $81,501.98$ and 83,616 and trainee teachers: $15,903.42$ and 21,020, respectively. Moreover, 10,920.49 and 20,169.38 teachers who did not hold a professional advancement grade were employed in 2013 and 2019.

The data presented above allow to state that both the level of initial teacher education, i.e. their initial qualifications, and continuing professional 
$\frac{\pi}{2}$

\begin{tabular}{|c|c|c|c|c|c|c|c|c|c|c|c|c|c|c|c|c|c|c|}
\hline 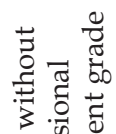 & 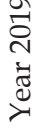 & $\stackrel{\text { I }}{\text { I }}$ & হ̄ & N & $\underset{m}{\vec{n}}$ & \&̊ & $\stackrel{\text { ? }}{\stackrel{2}{+}}$ & ষ্ণ & مิ & $\stackrel{\infty}{\infty}$ & $\begin{array}{l}N \\
\infty \\
\text { n) }\end{array}$ & $\begin{array}{l}\infty \\
\infty \\
\infty \\
\end{array}$ & 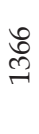 & f & 욤 & $\begin{array}{l}\infty \\
10 \\
10 \\
\end{array}$ & $\stackrel{N}{\alpha}$ & o \\
\hline 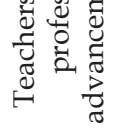 & 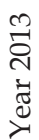 & $\begin{array}{l}\text { న్ } \\
\text { } \\
\infty\end{array}$ & 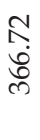 & 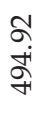 & $\begin{array}{l}\text { ळ } \\
\stackrel{+}{+} \\
\stackrel{\sim}{N}\end{array}$ & 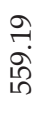 & $\begin{array}{l}\stackrel{+}{\sim} \\
\text { ন }\end{array}$ & 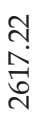 & 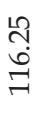 & 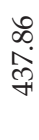 & $\begin{array}{l}\infty \\
\text { ๙் } \\
\text { থे }\end{array}$ & $\begin{array}{l}\infty \\
0 \\
\infty \\
\infty \\
\infty\end{array}$ & $\begin{array}{l}\hat{\aleph} \\
\text { ஸें }\end{array}$ & $\begin{array}{l}\infty \\
\infty \\
\infty \\
\infty \\
\infty\end{array}$ & $\begin{array}{l}\infty \\
0 \\
\text { ஸे } \\
\text { की }\end{array}$ & $\begin{array}{l}\text { నे } \\
\text { సे }\end{array}$ & $\begin{array}{l}\infty \\
\stackrel{\infty}{0} \\
\stackrel{0}{0}\end{array}$ & श़े. \\
\hline
\end{tabular}

$\frac{\pi}{8}$

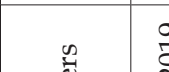

今)

胥

导

๘ี

m ปூ

")

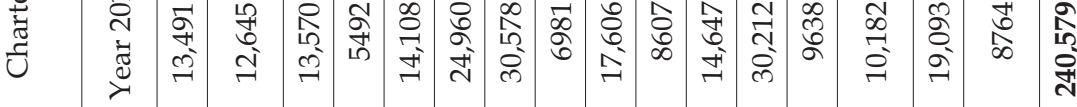

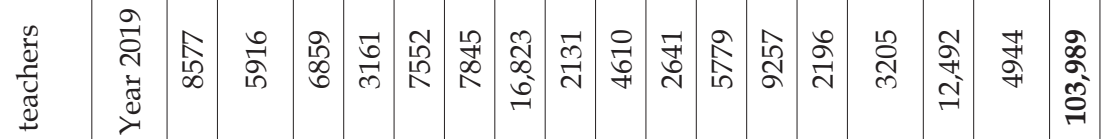

ำ

응

تृ

范

$\Xi$

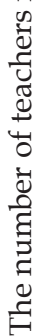

"

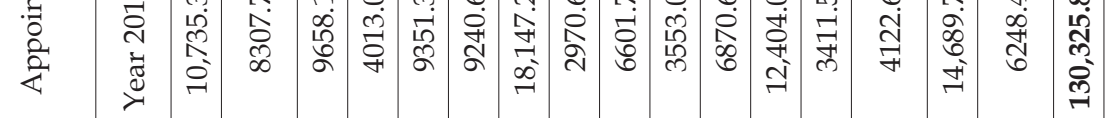

วิ)

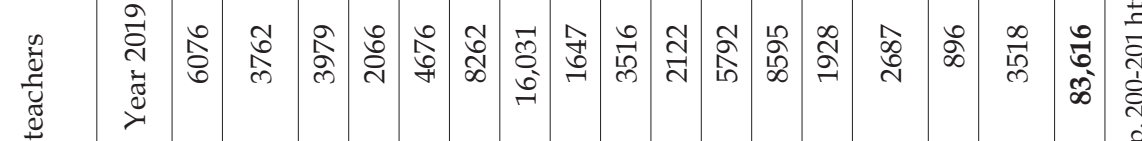

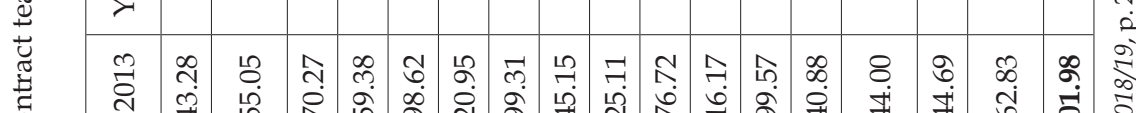

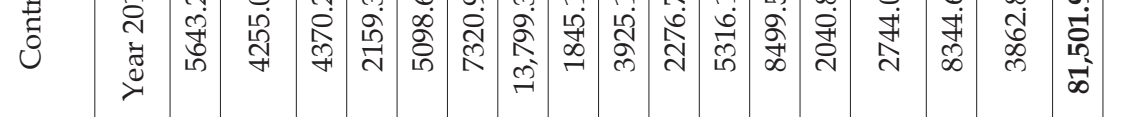

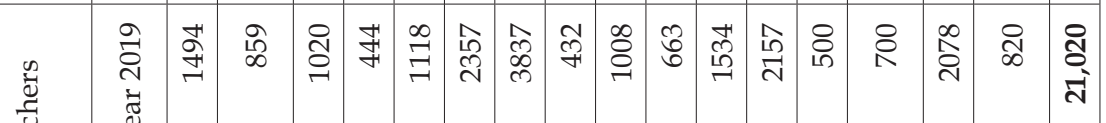

ฮ્ર

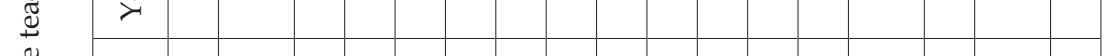

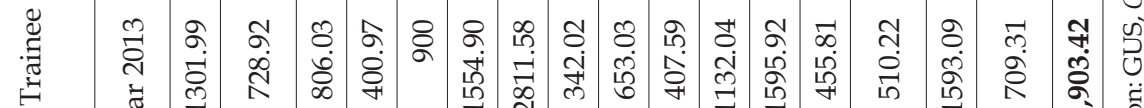

ซี

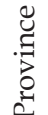

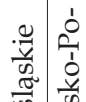


development constitute an important quality-related element of the education system. This is a result of both initial teacher education and in-service training systems, where "The assumption of the professional advancement system introduced in 2000 was to activate teachers in order to improve the education process". ${ }^{44}$

In accordance with the Teacher's Charter act, working hours of a full-time teacher cannot exceed 40 per week. At the same time, the aforementioned legal act sets out in detail obligatory weekly hours including subject teaching, educational and care elements, which involve both teaching classes and working on behalf of students. The number of these hours ranges from 15 to 30. The exception is working hours of form teachers during school residential trips, where 26 hours apply, out of which 10 hours are devoted to teaching.

Teacher's Charter also defines average teacher's salary, i.e.:

1) trainee teacher $\quad-100 \%$;

2) contract teacher $\quad-111 \%$;

3) appointed teacher $\quad-144 \%$;

4) chartered teacher $\quad-184 \%$

of base amount, which is annually determined in the budget act.

Teachers are entitled to a length-of-service allowance amounting to $1 \%$ of the basic pay for each year of employment, which is paid on a monthly basis, starting from the fourth year of employment, which may not, however, exceed $20 \%$ of basic pay. ${ }^{45}$

Teachers also receive jubilee awards for their long service that range from $75 \%$ of monthly salary after 20 years of work to $250 \%$ after 40 years of work.

\section{Summary}

Teachers are the foundation of changes that have taken place in Polish system of education since 1989. Subsequent reforms of the education system have changed not only the structure of the education system, curricula, and teachers' professional advancement system, but above all the way of thinking. The aim of the reforms was to start the process of preparing teachers for playing the role of mentors who are passionate about their profession and whose commitment contributes to a new quality of the education process.

${ }^{44}$ J. Michalak-Dawidziuk, Awans zawodowy nauczycieli jako proces dynamicznych zmian wspótczesna praktyka i perspektywa przyszłości, [in:] Edukacyjne konteksty wspótczesności. Z myśla o przyszłości, Eds. J. Madalińska-Michalak, N.G. Pikuła, Kraków 2018, p. 619.

${ }_{45}$ Art. 33(1) of the act of 26 January 1982 Teacher's Charter (O.J. of 2014, item 191, 1198, O.J. of 2015 item $357,1268,1418$. 
Teachers' passion for their profession is a measure of education quality. It forms the basis for shaping attitudes that create opportunities for young people to achieve their dreams, awake passions, and develop talents and interests. This way, you can find fulfilment in your professional work. ${ }^{46}$

Such an approach requires that teachers are aware of ethical dimension of their profession, which is based on professionalism, consolidated by practical experience and building relationships with students in order to support their development.

In a teacher's work, well-being of students should be the focal point, and teacher's maturity and a sense of responsibility should be the foundation of professional ethics. ${ }^{47}$

Hence the importance of teacher education, its multidimensional and comprehensive character, but also variability resulting from dynamic processes occurring in school environment. Reality, in which modern schools operate should be a determinant factor for teacher education. Therefore, initial teacher education requires shaping an attitude of openness and flexibility, but also the ability to make the most beneficial choices for student's development.

Changes observed in Polish system of teacher education resulting from the act of 20 July 2018 Law on Higher Education and Science and the Order of the Minister of Science and Higher Education of 25 July 2019 on standards of initial teacher education mainly focus on practical dimension of initial teacher education. This approach is justified by the need to prepare students for practising the teaching profession in conditions of dynamic changes, which require both professionalism expressed by holding effective pedagogical skills and competencies to ensure efficient decision making adequate to the situation. The importance of providing practical teaching experience in the process of initial teacher education is widely discussed in literature mentioned in this text. The view of R. Branderburg, A. McDonough \& J. Burke that "professional experience is regarded as a key element of teacher education programs" ${ }^{\prime 8}$ expressed in the article entitled Teacher education research and the policy reform agenda confirms such as understanding of the process of initial teacher education.

Taking into account the special role of education, which is ascribed to it by numerous documents published by European Union institutions, includ-

${ }^{46}$ I. Kust, Jak szkoła może pomóc uczniowi w odkrywaniu pasji? Analiza przypadku, Zeszyty Naukowe Forum Młodych Pedagogów przy Komitecie Nauk Pedagogicznych Polskiej Akademii Nauk, Zeszyt 19 - Opowiem wam o swojej pasji: stowem, obrazem, dźwiękiem, Lublin 2015, p. 187.

${ }^{47}$ I. Kust, Etyka nauczyciela na tle reformy programowej, [in:] Teacher's Ethics, Eds. M. Bajan, S.J. Żurek, Lublin 2011, p.79.

${ }^{48}$ R. Brandenburg, A. McDonough, J. Burke, Teacher education research and the policy reform agenda [in:] Teacher Education, p. 9. 
ing: Edukacja. Jest w niej ukryty skarb, ${ }^{49}$ Treaty on European Union and Treaty on the functioning of the European Union, ${ }^{50}$ Communication from the Commission to the European Parliament, the Council, the European Economic and Social Committee and the Committee of the Regions Rethinking Education: Investing in skills for better socio-economic outcomes, ${ }^{51}$ it is worth looking at teaching as a priority profession. It is the quality of education, and thus the level of preparing students for adult life, and in a broader perspective - the functioning of the whole society, that are contingent on teacher education. Therefore, an important aspect of initial teacher education are the predispositions of candidates for teacher training programmes.

In Finland, the number of candidates for teacher education programmes has doubled from 13,082 in 1998 to 26,783 in 2008 . Out of 26,783 candidates in 2008, only 3,076 were accepted. For comparison, in Denmark, from 1997 to 2007 graduation rates for teacher education programmes fell from $80 \%$ to $62 \% .{ }^{52}$

This result is influenced by "numerous differences between Finland and other Scandinavian countries in terms of culture and social status of the teaching profession". ${ }^{53}$

In Poland, the number of candidates for teacher education programmes dramatically diminishes. In the academic year 2013/14 the number of candidates for degree programmes in pedagogy was 16,227 , while in the academic year 2019/20 it was less than 8,000. The table below illustrates the phenomenon of successive decrease in popularity of degree programmes in pedagogy.

There are several reasons for this. Among them, only three key ones will be mentioned: instability resulting from permanent changes caused by frequent reforms of the education system, low salaries combined with the need for continuing professional development, high level of stress resulting from the complexity of educational problems of students accompanied by the demanding attitude of their parents. Also noteworthy is a long tradition of the lack of respect for the teaching profession in society. This sit-

${ }^{49}$ Edukacja. Jest w niej ukryty skarb: Raport dla UNESCO Międzynarodowej Komisji ds. Edukacji dla XXI wieku pod przewodnictwem Jacques'a Delorsa, transl. W. Rabczuk, Warszawa 1998.

${ }^{50}$ Treaty on European Union and Treaty on the Functioning of the European Union 2008/C 115/01 - consolidated version (O.J. of the EU 115/01) https:/ / eur-lex.europa.eu/resource [access: 20.02.2020].

${ }^{51}$ Communication from the Commission to the European Parliament, the Council, the European Economic and Social Committee and the Committee of the Regions Rethinking Education: Investing in skills for better socio-economic outcomes, Strasbourg, 20.11.2012. COM(2012) 669 final https:/ / eur-lex.europa.eu/legal-content/PL/TXT/PDF [access: 20.02.2020].

${ }_{52}$ H. Dorf, D. Reimer, J. Rasmussen, Who becomes a teacher - and why? Teacher recruitment in Denmark in a Nordic Comparative perspective, [in:] Teacher Education Policy in Europe Network, Eds J. Madalińska-Michalak, H. Niemi, S. Chong, Łódź 2012, p. 122

53 Ibidem, p. 123. 
uation can result from the recruitment for degree programmes in pedagogy, which has changed from negative selection (typical for the period before 1989) to random one, typical for the period of mass higher education.

Table 3

The number of candidates for first-cycle degree programmes in pedagogy from 2013/14 to 2019/20 academic year

\begin{tabular}{|c|c|}
\hline Academic Year & Number of candidates \\
\hline $2013 / 14$ & 16,227 \\
\hline $2014 / 15$ & 13,443 \\
\hline $2015 / 16$ & 13,137 \\
\hline $2016 / 17$ & 12,655 \\
\hline $2017 / 18$ & 12,732 \\
\hline $2018 / 19$ & 12,190 \\
\hline $2019 / 20$ & less than $8000^{55}$ \\
\hline
\end{tabular}

Source: Own work based on Information from the Ministry of Science and Higher Education, Department of Higher Education on the results of enrolment for the academic year 2013/14, $,^{55} 014 / 15,{ }^{56}$ $2015 / 16,{ }^{57} 2016 / 17,{ }^{58} 2017 / 18,{ }^{59} 2018 / 19^{60}$ and $2019 / 20^{61}$ in universities supervised by the Ministry of Science and Higher Education.

${ }^{54}$ The data in the source material included only degree programmes for which more than 8,000 candidates applied. The degree programmes in pedagogy did not meet this requirement, thus the lack of detailed data.

55 The Ministry of Science and Higher Education, Information from the Ministry of Science and Higher Education, Department of Higher Education on the results of recruitment for the academic year 2013-2014, https:/ / docplayer.pl/17473396-I-n-f-o-r-m-a-c-j-a-o-wynikach-rekrutacji-na-stu dia-na-rok-akademicki-2013-2014-w-uczelniach-nadzorowanych-przez-ministra-nauki-i-szkolnictwa-wyzszego.html [access: 11.02.2020] http://www.outsourcingportal.eu/pl/userfiles/image/raporty/2014/11/20/Informacjaowynikachrekrutacji.pdf [access: 11.02.2020]

${ }^{56}$ The Ministry of Science and Higher Education, Information from the Ministry of Science and Higher Education, Department of Higher Education on the results of recruitment for the academic year 2014-15 http://www.outsourcingportal.eu/pl/userfiles/image/raporty/2014/11/20/Infor macjaowynikachrekrutacji.pdf [access: 11.02.2020]

57 The Ministry of Science and Higher Education, Information from the Ministry of Science and Higher Education, Department of Higher Education on the results of recruitment for the academic year 2015-16, http://www.outsourcingportal.eu/pl/userfiles/image/raporty/2014/11/20/ Informacjaowynikachrekrutacji.pdf [access: 11.02.2020]

58 The Ministry of Science and Higher Education, Information from the Ministry of Science and Higher Education, Department of Higher Education on the results of recruitment for the academic year 2016-17 https://www.gov.pl/web/nauka/informacja-o-wynikach-rekrutacjina-studia-na-rok-akademicki-2016/2017 [access: 11.02.2020]

59 The Ministry of Science and Higher Education, Information from the Ministry of Science and Higher Education, Department of Higher Education on the results of recruitment for the academic year 2017/18 http://www.bip.nauka.gov.pl/komunikaty-rzecznika-prasowego -mnisw / znamy-wyniki-rekrutacji-na-studia-w-roku-2017-18.html [access: 11.02.2020]

${ }^{60}$ The Ministry of Science and Higher Education, Information from the Ministry of Science and Higher Education, Department of Higher Education on the results of recruitment for the academic year 2018/2019 www.gov.pl> 20181109_WYNIKI_rekrutacji_2018 19. [access: 11.02.2020]

${ }^{61}$ The Ministry of Science and Higher Education, Information from the Ministry of Science and Higher Education, Department of Higher Education on the results of recruitment for the 
In Poland, in the academic year 2015/16, 23,200 students were enrolled for the first year of degree programmes in pedagogy (as part of first- and second-cycle studies), ${ }^{62}$ while in the academic year 2018/19 there were 12,190 of them. ${ }^{63}$

Table 4

The number of students enrolled for degree programmes in pedagogy in Poland in the years 2015/16-2018/19

\begin{tabular}{|c|c|c|c|c|}
\hline \multirow{2}{*}{$\begin{array}{c}\text { The number } \\
\text { of students }\end{array}$} & \multicolumn{4}{|c|}{ Academic year } \\
\cline { 2 - 5 } & $2015 / 16$ & $2016 / 17$ & $2017 / 18$ & $2018 / 19$ \\
\cline { 2 - 5 } & 112.7 & 102.1 & 89.8 & 84.4 \\
\hline
\end{tabular}

Source: Szkoły wyższe $i$ ich finanse, GUS, Warszawa - Gdańsk 2019, p. 22 http://stat.gov.pl/ obszary-tematyczne/edukacja/ [access: 11.02.2020].

The decrease in the number of pedagogy students overlaps with gradual decrease in the overall number of students, which has been observed in Poland for several years and is a result of demographic decline. The table below illustrates this trend.

The number of students in Poland

Table 5 in the years 2005/10 - 2018/19 (including foreigners)

\begin{tabular}{|c|c|}
\hline Year & Total number of students \\
\hline $2005 / 10$ & $1,953,832$ \\
\hline $2010 / 11$ & $1,841,251$ \\
\hline $2015 / 16$ & $1,405,133$ \\
\hline $2016 / 17$ & $1,348,822$ \\
\hline $2018 / 19$ & $1,291,870$ \\
\hline $2018 / 19$ & $1,230,254$ \\
\hline
\end{tabular}

Source: Own work on the basis of: Szkoły wyższe i ich finanse, GUS, Warszawa - Gdańsk 2019, p. 16 http://stat.gov.pl/obszary-tematyczne/edukacja/ [access: 11 February 2020].

Despite the imperfections of the professional advancement system, including vast bureaucracy, continuing professional development has become an integral part of the teaching profession. This situation creates conditions

academic year 2019/20 https://www.gov.pl/web/nauka/najchetniej-na-informatyke-najtrudniej-na-orientalistyke--znamy-wyniki-rekrutacji-na-studia-w-roku-20192020 [access: 11.02.2020].

${ }^{62}$ Szkoty wyższe $i$ ich finanse w 2015 r., GUS, Warszawa 2016, p. 62, http:/ / www.stat.gov.pl [access: 12.02.2020].

${ }^{63}$ Szkoły wyższe i ich finanse, GUS, Warszawa - Gdańsk 2019, p. 22 http:/ / stat.gov.pl/obszary-tematyczne/edukacja/ [access: 11. 02.2020]. 
for shaping a new image of a teacher who is a professional, open to modern teaching methods and who forms relationships with students based on partnership.

... education faces a fundamental transition - from preparing individuals for being useful to institutions, through the performance of various roles and expecting remuneration for their fulfilment, to equipping individuals for becoming useful for themselves by attaining their own goals and satisfying their desires, and thus becoming useful to others and to institutions. ${ }^{64}$

\section{BIBLIOGRAPHY}

Banach C., Orientacje - konteksty - kategorie - praktyki, Wydawnictwo Edukacyjne, Kraków 1998.

Brandenburg R., McDonough A., Burke J., Teacher education research and the policy reform agenda, [in:] Teacher Education. Innovation, Intervention and Impact, Eds. R. Brandenburg, A. McDonough, J. Burke, Springer Science+Business Media, Singapore 2016.

Combs A.W., Blume R.A., Newman A.J., Wass H.L., The Professional Education of Teachers, Boston Allyn and Bacon, Inc., 1978.

Dorf H., Reimer D., Rasmussen J., Who becomes a teacher - and why? Teacher recruitment in Denmark in a Nordic Comparative perspective, [in:] Teacher Education Policy in Europe Network, Eds. J. Madalińska-Michalak, H. Niemi, S. Chong, Wydawnictwo Uniwersytetu Łódzkiego, Łódź 2012.

Edukacja. Jest w niej ukryty skarb: Raport dla UNESCO Międzynarodowej Komisji ds. Edukacji dla XXI wieku pod przewodnictwem Jacques'a Delorsa, transl. W. Rabczuk, Stowarzyszenie Oświatowców Polskich, Wydawnictwo UNESCO, Warszawa 1998.

Forgasz R., Rethinking the Observation Placement: A Community/Cohort Approach to Early Professional Experiences, [in:] Teacher Education. Innovation, Intervention and Impact, Eds. R. Brandenburg, A. McDonough, J. Burke, Springer Science+Business Media, Singapore 2016.

Gołębniak B.D., Zmiany edukacji nauczycieli: wiedza - biegłość - refleksyjność, Wydawnictwo Edytor, Torun - Poznań 1998.

Gore J.M., Reform and the Reconceptualisation of teacher education in Australia, [in:] Teacher Education. Innovation, Intervention and Impact, Eds. R. Brandenburg, A. McDonough, J. Burke, Springer Science+Business Media, Singapore 2016.

Gore J.M., Griffiths T.G., Ladwig J.G., Towards better teaching: Productive pedagogy as a framework for teacher education, Teaching and Teacher Education, 2004, 20.

Jones I., Integrating Service Learning into Early Childhood Teacher Education: A theoretical perspective, [in:] Service learning as pedagogy in early childhood education. Theory, Research, and Practice, Ed. K.L. Heider, Springer International Publishing Switzerland 2017.

Kust I., Etyka nauczyciela na tle reformy programowej, [in:] Teacher's Ethics, Eds. M. Bajan, S.J. Żurek, Towarzystwo Naukowe Katolickiego Uniwersytetu Lubelskiego Jana Pawła II, Lublin 2011.

Kust I., Jak szkoła może pomóc uczniowi w odkrywaniu pasji? Analiza przypadku, Zeszyty Naukowe Forum Młodych Pedagogów przy Komitecie Nauk Pedagogicznych Polskiej Akademii Nauk, Zeszyt 19 - Opowiem wam o swojej pasji: słowem, obrazem, dźwiękiem,

\footnotetext{
${ }^{64}$ H. Kwiatkowska, Pedeutologia, p. 244.
} 
Katolicki Uniwersytet Lubelski Jana Pawła II, Instytut Pedagogiki, Wydawnictwo ACADEMY-CON, Lublin 2015.

Kwiatkowska H., Nowa orientacja w kształceniu nauczycieli. Założenia i metody edukacji nauczycielskiej, Państwowe Wydawnictwo Naukowe, Warszawa 1988.

Kwiatkowska H., Edukacja nauczycieli. Konteksty - kategorie - praktyki, Instytut Badań Edukacyjnych, Warszawa 1997.

Kwiatkowska H., Kształcenie nauczycieli, [in:] Encyklopedia pedagogiczna XXI wieku, Vol. 2, Ed. T. Pilch, Wydawnictwo Akademickie Żak, Warszawa 2003.

Kwiatkowska H., Pedeutologia, Wydawnictwa Akademickie i Profesjonalne, Warszawa 2008.

Lewowicki T., Model zróżnicowanej szkoły wyższej, Instytut Polityki Naukowej, Postępu Technicznego i Szkolnictwa Wyższego, Warszawa 1985.

Lewowicki T., Problemy ksztatcenia i pracy nauczycieli, Instytut Technologii Eksploatacji PIB, Warszawa - Radom 2007.

Loughran J., Developing a pedagogy of teacher education Understanding teaching and learning about teaching, Taylor \& Francis Group, London - New York 2006.

Madalińska-Michalak J., Góralska R., Kompetencje społeczne nauczyciela, Wolters Kluwer, Warszawa 2012.

Michalak-Dawidziuk J., Kompetencje społeczne a utopia, [in:] Utopia and Education, Ed. R. Włodarczyk, Vol. II, Instytut Pedagogiki Uniwersytetu Wrocławskiego, Wrocław 2017.

Michalak-Dawidziuk J., System awansu zawodowego nauczycieli a transgresyjna postawa nauczycieli, [in:] Transgresja jako motyw refleksji nad wychowaniem, Eds. A. Ciążela, S. Jaronowska, Wydawnictwo Akademii Pedagogiki Specjalnej, Warszawa 2017.

Michalak-Dawidziuk J., Awans zawodowy nauczycieli jako proces dynamicznych zmian wspótczesna praktyka i perspektywa przyszłości, [in:] Edukacyjne konteksty wspótczesności. Z myślą o przyszłości, Eds. J. Madalińska-Michalak, N.G. Pikuła, Oficyna Wydawnicza Impuls, Kraków 2018.

Moore A., Teaching and learning: Pedagogy, Curriculum and culture, Routledge, Taylor \& Francis Group, London - New York 2012.

Niemiec J., Wyznaczniki modeli ksztatcenia nauczycieli, [in:] Alternatywne modele ksztatcenia nauczycieli, Ed. M. Ochmański, Wydawnictwo UMCS, Lublin 1995.

Nowacki T.W., Leksykon pedagogiki pracy, Instytut Technologii Eksploatacji, Radom 2004.

Wiłkomirska A., Zielińska A., Ocena systemu awansu zawodowego nauczycieli w Polsce, Wydawnictwo Uniwersytetu Warszawskiego, Warszawa 2013.

Pearson A., Nauczyciel. Teoria i praktyka w ksztatceniu nauczycieli, Wydawnictwa Szkolne i Pedagogiczne, Warszawa 1994.

O'Keeffe D., Teacher education in Britain, Edukacja, 2003, 3(83).

Okoń W., Kształcenie nauczycieli w Polsce - stan i kierunki przebudowy, Państwowe Wydawnictwo Naukowe, Warszawa - Kraków 1988.

Okoń W., Rzecz o edukacji nauczycieli, Wydawnictwa Szkolne i Pedagogiczne, Warszawa 1991.

Pachociński R., Edukacja nauczycieli w krajach Unii Europejskiej, Instytut Badań Edukacyjnych, Warszawa 1994.

Pietrasiński Z., Wstęp do czynnościowej teorii kształcenia umystu, [in:] Studia nad teoria czynności ludzkich, Eds. I. Kurcz, J. Reykowski, Państwowe Wydawnictwo Naukowe, Warszawa 1975.

Rumiński A., Aksjologia pedagogiczna w ksztatceniu nauczycieli, [in:] Akademicka edukacja nauczycieli. Z problemów metodologii, teorii i praktyki, Ed. K. Duraj-Nowakowska, Wydawnictwo Naukowe WSP, Kraków 1993. 
Szempruch J., Aksjologia w kształceniu i dziataniu nauczycieli zreformowanej szkoty, Nowa Szkoła, 2000, 4.

Szempruch J., Pedagogiczne kształcenie nauczycieli wobec reformy systemu edukacji w Polsce, Wydawnictwo WSP, Rzeszów 2000.

Szempruch J., Pedeutologia, Studium teoretyczno-pragmatyczne, Oficyna Wydawnicza Impuls, Kraków 2013.

Teacher Education Ministerial Advisory Group (TEMAG), Action now: Classroom ready teachers. Canberra, Australia: Department of Education and Training, 2014.

The Holmes Group Tomorrow's Teachers, East Lansing, MI, The Holmes Group 1986.

Waring M., Evans C., Understanding Pedagogy, Developing a critical approach to teaching and learning, Routledge, London 2014.

Wiłkomirska A, Ocena kształcenia nauczycieli w Polsce, Instytut Spraw Publicznych, Warszawa 2005.

Wiłkomirska A, Zielińska A., Ocena systemu awansu zawodowego nauczycieli w Polsce, Wydawnictwa Uniwersytetu Warszawskiego, Warszawa 2013.

Zeichner K.M., Tabachnik B.R., Are the effects of University teacher education "washed out" by school experiences? Journal of Teacher Education, 1981, 32(2).

\section{Legal regulations}

Treaty on European Union and Treaty on the Functioning of the European Union 2008/C 115/01 consolidated version (O.J. of the EU 115/01) [access: 20.02.2020] https://eur-lex. europa.eu/resource.

Communication from the Commission to the European Parliament, the Council, the European Economic and Social Committee and the Committee of the Regions Rethinking Education: Investing in skills for better socio-economic outcomes, Strasbourg, 20.11.2012. $\operatorname{COM}(2012) 669$ final https:/ / eur-lex.europa.eu/legal-content/PL/TXT/PDF [access: 20.02.2020].

Ustawa z 26 stycznia 1982 r. Karta Nauczyciela (DzU z 2019 r. poz. 2215).

Ustawa z 27 lipca 2005 r. Prawo o szkolnictwie wyższym (DzU 2005 r., nr 164, poz. 1365 z późn. $\mathrm{zm}$.).

Ustawa z 20 lipca 2018 r. Prawo o Szkolnictwie Wyższym i Nauce (DzU z 2020 r., poz. 85).

Rozporządzenie Ministra Nauki i Szkolnictwa Wyższego z 12 lipca 2007 r. w sprawie standardów ksztatcenia dla poszczególnych kierunków i poziomów ksztatcenia, a także trybu tworzenia i warunków, jakie musi spetniać uczelnia, by prowadzić studia międzykierunkowe oraz makrokierunki (DzU z 2007 r., nr 164, poz. 1166 z późn. zm.).

Rozporządzenie Ministra Nauki i Szkolnictwa Wyższego z 17 stycznia 2012 r. w sprawie standardu kształcenia przygotowujacego do wykonywania zawodu nauczyciela (DzU z 2012 r., poz. 131).

Rozporządzenie Ministra Edukacji Narodowej z 1 sierpnia 2017 r. w sprawie szczegótowych kwalifikacji wymaganych od nauczycieli (DzU z 2017 r., poz. 1575).

Rozporządzenie Ministra Nauki i Szkolnictwa Wyższego z 25 lipca 2019 r. w sprawie standardów ksztatcenia przygotowującego do wykonywania zawodu nauczyciela (DzU z 2019 r., poz. 1450).

\section{Internet sources}

GUS, Oświata i wychowanie. Rok szkolny 2012/13, p. 250-251; http://stat.gov.pl [access: 9.02.2020]. 
GUS, Oświata i wychowanie. Rok szkolny 2018/19, p. 200-201; http:/ / stat.gov.plobszary-tematyczne/edukacja [access: 9.02.2020].

http://www.outsourcingportal.eu/pl/userfiles/image/raporty/2014/11/20/Informacjaowynikachrekrutacji.pdf [access: 11.02.2020].

McKenzie P., Weldon P., Rowley G., Murphy M., McMillan J., Staff in Australia's School 2013: Main report on the survey, 2014 https://docs.education,gov.au/system/files/ doc/other/sias 2013mainreport.pdf

Ministerstwo Nauki i Szkolnictwa Wyższego, Informacja Ministerstwa Nauki i Szkolnictwa Wyższego, Departament Szkolnictwa Wyższego o wynikach rekrutacji na studia na rok akademicki2013-2014 https:// docplayer.pl/17473396-I-n-f-o-r-m-a-c-j-a-o-wynikach-rekrutacji-na-studia-na-rok-akademicki-2013-2014-w-uczelniach-nadzorowanych-przez-ministra-nauki-i-szkolnictwa-wyzszego.html [access: 11.02.2020].

Ministerstwo Nauki i Szkolnictwa Wyższego, Informacja Ministerstwa Nauki i Szkolnictwa Wyższego, Departament SzkolnictwaWyższegoo wynikach rekrutacjina studia na rokakademicki 2014-15 http:/ / www.outsourcingportal.eu/pl/userfiles/image/raporty/2014/11/ 20/Informacjaowynikachrekrutacji.pdf [access: 11.02.2020].

Ministerstwo Nauki i Szkolnictwa Wyższego, Informacja Ministerstwa Nauki i Szkolnictwa Wyższego, Departament Szkolnictwa Wyższego o wynikach rekrutacji na studia na rok akademicki 2015-16, http:/ / www.outsourcingportal.eu/pl/userfiles/image/raporty/2014/ 11/20/Informacjaowynikachrekrutacji.pdf [access: 11.02.2020].

Ministerstwo Nauki i Szkolnictwa Wyższego, Informacja Ministerstwa Nauki i Szkolnictwa Wyższego, Departament Szkolnictwa Wyższego o wynikach rekrutacji na studia na rok akademicki 2016-17 https:/ / www.gov.pl/web/nauka/informacja-o-wynikach-rekrutacji-na-studia-na-rok-akademicki-2016/2017 [access: 11.02.2020].

Ministerstwo Nauki i Szkolnictwa Wyższego, Informacja Ministerstwa Nauki i Szkolnictwa Wyższego, Departament Szkolnictwa Wyższego o wynikach rekrutacji na studia na rok akademicki 2017/18 http://www.bip.nauka.gov.pl/komunikaty-rzecznika-prasowegomnisw/znamy-wyniki-rekrutacji-na-studia-w-roku-2017-18.html [access: 11.02.2020].

Ministerstwo Nauki i Szkolnictwa Wyższego, Informacja Ministerstwa Nauki i Szkolnictwa Wyższego, Departament Szkolnictwa Wyższego o wynikach rekrutacji na studia na rok akademicki 2018/19 www.gov.pl>20181109_WYNIKI_rekrutacji_2018-2019.pdf [access: 11.02.2020].

Ministerstwo Nauki i Szkolnictwa Wyższego, Informacja Ministerstwa Nauki i Szkolnictwa Wyższego, Departament Szkolnictwa Wyższego o wynikach rekrutacji na studia na rok akademicki 2019/20 https://www.gov.pl/web/nauka/najchetniej-na-informatyke-naj trudniej-na-orientalistyke--znamy-wyniki-rekrutacji-na-studia-w-roku-2019 2020 [access: 11.02.2020].

Shulman L.S., Those who understand: Knowledge growth in teaching, Educational Researcher, 1986, 15(2), p. 4-14; http://www.jstor.org.stable/1175860

Szkoty wyższe $i$ ich finanse w 2015 r., GUS, Warszawa 2016, p. 62; http:/ /www.stat.gov.pl [access: 12.02.2020].

Szkoty wyższe i ich finanse, GUS, Warszawa - Gdańsk 2019, p. 22; http:/ / stat.gov.pl/obszary-tematyczne/edukacja/ [access: 11.02 .2020 ].

Szkoty wyższe i ich finanse w 2018 r., GUS, Warszawa - Gdańsk 2019, p. 16; http:/ / stat.gov. pl/obszary-tematyczne/edukacja/ [access: 11.02. 2020]. 